\title{
BIODIVERSITY AND POPULATION DISTRIBUTION OF FRUIT FLY (Diptera: Tephritidae) IN DOMESTIC ORCHARDS OF PARAÍBA STATE, BRAZIL ${ }^{1}$
}

\author{
JOÁLISSON GONÇALVES DA SILVA², CARLOS HENRIQUE DE BRITO², ROBÉRIO DE OLIVEIRA²*, ELTON \\ LÚCIO ARAÚJO ${ }^{4}$, KENNEDY SANTOS GONZAGA ${ }^{2}$, GLEIDYANE NOVAIS LOPES ${ }^{5}$
}

\begin{abstract}
The objective of this study was to characterize, through faunistic indices, the populations of fruit flies in the Brejo Paraibano microregion and analyze whether these populations are similar to one another. The study was conducted in eight municipalities located in the Agreste Paraibano mesoregion and Brejo Paraibano microregion, Paraíba state, Brazil, where two rural properties of each municipality were selected, georeferenced and identified according to the diversity criterion of fruit species. Each municipality was assumed to have a population of fruit flies with its own characteristics, determined by the faunistic indices of frequency, constancy, dominance, Shannon-Wiener and Margalef diversity indices, as well as evenness. 3.159 specimens of fruit flies were captured, of which $85.57 \%$ belonged to the genus Anastrepha and $14.43 \%$ to the genus Ceratitis. 11 species of fruit flies were captured in the traps. Anastrepha fraterculus was the most frequent, dominant and constant species, being present in all locations; followed by A. obliqua, A. sororcula and Ceratitis capitata. The studied municipalities have a similarity of $54 \%$, which indicates a high similarity between the areas. Most species captured in the present study occur at low population frequency.
\end{abstract}

Keywords: Population dynamics. Faunistic index. Similarity.

\section{BIODIVERSIDADE E DISTRIBUIÇÃO POPULACIONAL DE MOSCAS-DAS-FRUTAS (Diptera: Tephritidae) EM POMARES DOMÉSTICOS DO ESTADO DA PARAÍBA, BRASIL}

RESUMO - O trabalho teve por objetivo caracterizar, por meio de índices faunísticos, as populações de moscas-das-frutas no Brejo Paraibano, e analisar se essas populações são similares entre si. A pesquisa foi desenvolvida em oito municípios situados na Mesorregião do Agreste Paraibano e Microrregião do Brejo Paraibano, nos quais foram selecionadas duas propriedades rurais de cada município, georreferenciadas, identificadas segundo o critério de diversidade de espécies frutíferas. Cada município foi considerado como tendo uma população das moscas-das-frutas com características próprias, determinadas pelos índices faunísticos de frequência, constância, dominância, índices de diversidade de Shannon-Wiener e de Margalef, além de equitabilidade. Foram capturados 3.159 espécimes de moscas-das-frutas, dos quais $85,57 \%$ pertenciam ao gênero Anastrepha e 14,43\% o gênero Ceratitis. Foram capturadas onze espécies de moscas-das-frutas nas armadilhas. Anastrepha fraterculus foi a espécie mais frequente, dominante e constante, estando presente em todas as localidades; seguida das espécies A. obliqua, A. sororcula e Ceratitis capitata. Os municípios estudados apresentam similaridade de $54 \%$, o que indica alta semelhança entre as áreas. A maioria das espécies capturadas no presente estudo ocorre em baixa frequência populacional.

Palavras-chave: Dinâmica populacional. Índice faunístico. Similaridade.

${ }^{4}$ Departament of Agricultural Sciences, Universidade Federal Rural do Semi-Árido, Mossoró, RN, Brazil; elton@ufersa.edu.br - ORCID: 0000-0001-8274-502X.

${ }_{5}^{5}$ Departament of Phytotechny and Environmental Sciences, Universidade Federal da Paraíba, Areia, PB, Brazil; gleidyane@yahoo.com.br ORCID: 0000-0002-1455-3760.
} 


\section{INTRODUCTION}

The fruit flies of greatest economic importance in the country are basically Ceratitis capitata (Wiedemann, 1824) and Anastrepha spp. (ZUCCHI, 2000a). The genus Anastrepha has 121 species in Brazil, which are found in all regions, infesting a great diversity of native and cultivated fruits (ZUCCHI; MORAES, 2008; NORRBOM et al., 2014). Ceratitis capitata is an exotic species and the only representative of its kind in the country (ZUCCHI, 2000b). Despite the large number species of the genus Anastrepha described nationally, only 8 have been recorded in the state of Paraíba (ALVES et al., 2019a; ALVES et al., 2019b; SILVA et al., 2019).

Information on the faunistic analysis of tephritids is crucial for understanding the bioecology of these insects in different areas (MARSARO JÚNIOR et al., 2012). Therefore, several studies have been conducted around the world using food traps in order to know the diversity, monitor and/or control tephritids (ORDANO et al., 2013; TAIRA et al., 2013; ALI et al., 2014).

In adopting any program of integrated management of fruit flies in orchards, it is necessary to know some ecological aspects of these tephritids, such as the diversity of species present in orchards, frequency, dominance, constancy of species, among other faunistic parameters (AGUIAR-MENEZES et al., 2008).

Most faunistic studies on fruit flies conducted in orchards in several Brazilian states have demonstrated the dominance of only one or two species, even where high diversity was recorded (SÁ et al., 2012). Several factors, such as climate, orchard location and abundance and diversity of hosts, can influence fruit fly species.

The combination of taxonomic, biological and behavioral studies becomes a tool of great value for the real understanding of these organisms (DEUS; ADAIME, 2013). Thus, the objective of this study was to characterize, through faunistic analysis, the populations of fruit flies in the Brejo Paraibano microregion, besides analyzing whether these populations are similar to each other.

\section{MATERIAL AND METHODS}

The study area is located in the Agreste Paraibano mesoregion and Brejo Paraibano microregion, including the municipalities of Alagoa Grande $\left(07^{\circ} 01\right.$ ' 53.6” S, 35 38' 12.1 ” W; $\left.138 \mathrm{~m}\right)$, Alagoa Nova (07 $04^{\circ} 56.3^{\prime}$ ' S, $35^{\circ} 48^{\prime} 53.1$ ' W; 463 $\mathrm{m}$ ), Areia (6 $6^{\circ} 58^{\prime} 03.4^{\prime \prime} \mathrm{S}, 35^{\circ} 42^{\prime} 00.6^{\prime \prime} \mathrm{W} ; 573 \mathrm{~m}$ ), Bananeiras $\left(06^{\circ} 43^{\prime} 44.3^{\prime \prime} \mathrm{S}, 35^{\circ} 39^{\prime} 24.0^{\prime \prime} \mathrm{W} ; 544\right.$ $\mathrm{m})$, Borborema $\left(06^{\circ} 47^{\prime} 37.7^{\prime} \mathrm{S}, 35^{\circ} 35^{\prime} 53.2^{\prime}\right.$ ' W; $330 \mathrm{~m}$ ), Matinhas (07०06'40.0” S, $35^{\circ} 49^{\prime} 10.5^{\prime \prime} \mathrm{W}$;
$574 \mathrm{~m}$ ), Pilões $\left(06^{\circ} 56^{\prime} 45.4^{\prime \prime} \mathrm{S}, 35^{\circ} 39^{\prime} 38.2^{\prime \prime} \mathrm{W}\right.$; $436 \mathrm{~m})$ and Serraria $\left(06^{\circ} 49^{\prime} 03.8^{\prime \prime} \mathrm{S}, 35^{\circ} 39^{\prime} 19.4^{\prime \prime}\right.$ $\mathrm{W} ; 479 \mathrm{~m})$. The study was conducted in two rural properties of each municipality, which were chosen based on the criterion of having domestic orchards that had crops that were hosts of fruit flies. In each property, two host crops were chosen and two traps were installed in each, totaling four traps, which were georeferenced and identified according to the diversity criterion of fruit species. The population survey was conducted from July 2015 to June 2016.

Adult individuals of fruit flies were obtained with traps made from PET-type bottles, each of which with three holes with $10 \mathrm{~cm}$ in diameter, and these traps were installed in the host crops through hooks made with wires, with two traps/plant installed in each sampling area. The traps were placed at $1 \mathrm{~m} 30 \mathrm{~cm}$ from the ground in the host crops, containing $300 \mathrm{~mL}$ of $5 \%$ hydrolyzed protein aqueous solution $\left(\right.$ BioAnastrepha $\left.{ }^{(\mathbb{R}}\right)$ as food attractant.

The containers were inspected every two weeks, and their food attractant was substituted and sent to the Laboratory of Zoology of Invertebrates of the Center of Agricultural Sciences of the Federal University of Paraíba - Areia / PB. The specimens of fruit flies were quantified, properly labeled and kept in $70 \%$ ethanol for specific later identification. Anastrepha species were identified based on morphological characters of females according to Zucchi (2000a). The specimens were deposited in the entomological collection of the Invertebrate Zoology Laboratory of the aforementioned institution. The collected females of the Anastrepha genus were identified by Dr. Clarice Diniz Alvarenga Corsato State University of Montes Claros, Janaúba, MG.

Each municipality was assumed to have a population of fruit flies with its own characteristics, determined by the faunistic indices of frequency, constancy, dominance, Shannon-Wiener and Margalef diversity indices, as well as evenness (SILVEIRA NETO, 1990; SOUTHWOOD, 1995; PINTO-COELHO, 2000), justifying the following assessments:

Frequency: $\mathrm{pi}=\mathrm{ni} / \mathrm{N}$, where ni: Number of individuals of the species and $\mathrm{N}$ : total number of individuals in the sample. It is the proportion of individuals of a species in relation to the total number of individuals in the sample.

Constancy: Percentage of samples in which a given species was present. $C=p .100 / N$, where $p$ : number of samples with the species and $\mathrm{N}$ : total number of samples considered. Classification of species regarding constancy: constant (present in more than $50 \%$ of the samples), accessory (present in $25-50 \%$ of the samples), accidental (present in less than $25 \%$ of the samples).

Richness (S): Total number of species observed in the community.

Number of dominant species: A species is 
considered dominant when it has a frequency greater than $1 / \mathrm{S}$, where $\mathrm{S}$ is the total number of species in the community.

Shannon-Wiener ( $\left.\mathrm{H}^{\prime}\right)$ : Measures the degree of uncertainty in predicting to which species a randomly chosen individual will belong, from a sample with $\mathrm{S}$ species and $\mathrm{N}$ individuals.

Evenness: determined based on the ratio between the Shannon-Wiener diversity index (H') and the maximum diversity $\left(\mathrm{H}^{\prime} \max =\ln \mathrm{S}\right)$.

Margalef: This index expresses the relationship between the number of species and the number of individuals of each species and represents the pattern in the use of niches by the species.

The similarity between municipalities in terms of the composition of fruit fly species was determined by the Jaccard's method between the representative samples of the municipalities, which calculates the mean similarity between the samples using the software Past version 3.22 (HAMMER; HARPER; RYAN, 2001).

\section{RESULTS AND DISCUSSION}

In the eight municipalities studied, 3.159 specimens of fruit flies were captured, of which $85.57 \%$ belonged to the genus Anastrepha (1.867 females and 836 males) and $14.43 \%$ to Ceratitis (330 females and 126 males). Ten species of Anastrepha were captured in the traps, represented by the species A. antunesi Lima, 1938, A. barbiellinii Lima, 1938, A. dissimilis Stone, 1942, A. distincta Greene, 1934, A. fraterculus (Wiedemann, 1830), A. hadropickeli Canal, Uramoto and Zucchi, 2013, A. obliqua (Macquart, 1835), A. pickeli Lima, 1934, $A$. sororcula Zucchi, 1979, and A. zenildae Zucchi, 1979; while for the genus Ceratitis only one species was captured, $C$. capitata (Table 1 ).

Of the seven species of the fruit flies that are important from an economic point of view, due to the damage they cause to fruit crops ( $\mathrm{ZUCCHI}$; MORAES, 2012), four species were captured: $A$. obliqua, A. fraterculus, $A$. sororcula and $A$. zenildae.

Studies have reported that in the state of Paraíba, there are only eight species of Anastrepha, namely $A$. antunesi, $A$. fraterculus, A. obliqua, $A$. serpentina (Wiedmann, 1830), A. sororcula and $A$. zenildae (ZUCCHI; MORAES, 2008); and $A$. dissimilis and A. hadropickeli (ALVES et al., 2019a).

Anastrepha fraterculus was the most abundant species in the traps $(39.33 \%)$, followed by A. obliqua $(24.35 \%)$, A. sororcula $(17.39 \%)$ and $C$. capitata $(15.02 \%)$. The other species obtained an abundance of less than 50 specimens, totaling 3.91\% of the total females collected.

Regarding species richness, differences were observed between the analyzed municipalities. The highest richness was observed in Bananeiras and Serraria $(S=8)$ and the lowest richness was found in Borborema, Matinhas and Pilões $(S=5)$. This difference was determined by the capture of some species only in a given municipality. However, $A$. fraterculus, $A$. obliqua and $A$. sororcula occurred in the eight municipalities, and $C$. capitata was not captured only in Borborema (Table 1).

Studies conducted in several localities, with climate and vegetation similar to those observed in the present study, have also found low richness of fruit fly species. In southwestern Bahia, eight species were recorded in three municipalities (SÁ et al., 2012). The composition of the predominant species in each locality consisted of the species that reached the highest categories in the faunistic parameters used (abundance, dominance, frequency and constancy) (Table 1).

In relation to the predominant species, there was variation between the municipalities. Serraria (530), Bananeiras (491) and Areia (400) were the localities with highest abundance, resulting in the highest number of females captured among the eight municipalities $(64.68 \%$ of the total females captured in all the traps installed).

Anastrepha fraterculus was the most frequent, dominant and constant species, being present in all localities, followed by $A$. obliqua, $A$. sororcula and $C$. capitata, which were frequent, dominant and constant in certain municipalities studied (Table 1), corroborating several studies involving the faunistic analysis of tephritids, which found the occurrence of two to three dominant species in different regions of Brazil (HUSCH et al., 2012; MARSARO JÚNIOR et al., 2012; ARAUJO et al., 2013).

Species such as $A$. antunesi, $A$. distincta, $A$. dissimilis and $A$. zenildae were characterized as accidental and showed frequency of less than $3 \%$. The occurrence of other less frequent species of fruit flies in orchards may be due to the presence of preferential host plants and/or native vegetation near the orchards, which may have contributed to the occurrence of accessory and/or accidental species in the samples collected (AZEVEDO et al., 2010).

Anastrepha pickeli, A. hadropickeli and A. barbiellini occurred sporadically, also accidentally, with only one female of each sampled species, in different locations (Alagoa Grande, Alagoa Nova and Bananeiras, respectively) (Table 1). These species within each agroecosystem suggest how wide the diversity of fruit flies is and how well adapted they are to the environment in which they live. The presence of rare species indicates that the areas contain specific hosts, which increase the diversity of fruit flies. In addition, for the stability of a community, species that are rare, although economically unimportant, perform important indirect functions for the survival and maintenance of diversity of the community. 
Table 1. Characterization of fruit fly populations captured in traps, through faunistic analysis, in eight municipalities of the Brejo Paraibano microregion.

\begin{tabular}{|c|c|c|c|c|c|c|c|c|c|c|c|c|c|c|c|}
\hline \multirow[b]{3}{*}{ SPECIES } & \multicolumn{15}{|c|}{ BREJO PARAIBANO } \\
\hline & \multicolumn{4}{|c|}{ ALAGOA GRANDE } & \multicolumn{4}{|c|}{ LAGOA NOVA } & \multicolumn{4}{|c|}{ AREIA } & \multicolumn{3}{|c|}{ BANANEIRAS } \\
\hline & $\mathrm{N}$ & $\mathrm{F}$ & $\mathrm{C}$ & $\mathrm{D}$ & $\mathrm{N}$ & $\mathrm{F}$ & $\mathrm{C}$ & $\mathrm{D}$ & $\mathrm{N}$ & $\mathrm{F}$ & $\mathrm{C}$ & $\mathrm{D}$ & $\mathrm{N}$ & $\mathrm{F}$ & $\mathrm{C}$ \\
\hline A. fraterculus & 1 & 1.11 & $\mathrm{Z}$ & $\mathrm{N}$ & 126 & 40.00 & W & $\mathrm{D}$ & 265 & 66.25 & W & $\mathrm{D}$ & 131 & 26.68 & W \\
\hline A. obliqua & 17 & 18.89 & W & $\mathrm{D}$ & 11 & 3.49 & Z & $\mathrm{N}$ & 77 & 19.25 & W & $\mathrm{D}$ & 52 & 10.59 & $\mathrm{Y}$ \\
\hline A. sororcula & 1 & 1.11 & $\mathrm{Z}$ & $\mathrm{N}$ & 123 & 39.05 & W & $\mathrm{D}$ & 30 & 7.50 & $\mathrm{Y}$ & $\mathrm{N}$ & 158 & 32.18 & W \\
\hline A. antunesi & - & - & & & - & - & & & 11 & 2.75 & $\mathrm{Z}$ & $\mathrm{N}$ & 10 & 2.04 & Z \\
\hline A. distincta & 2 & 2.22 & $\mathrm{Z}$ & $\mathrm{N}$ & 2 & 0.63 & $\mathrm{Z}$ & $\mathrm{N}$ & 1 & 0.25 & $\mathrm{Z}$ & $\mathrm{N}$ & 14 & 2.85 & $\mathrm{Z}$ \\
\hline A. dissimilis & - & - & & & 1 & 0.32 & $\mathrm{Z}$ & $\mathrm{N}$ & - & - & & & - & - & \\
\hline A. zenildae & - & - & & & - & - & & & 2 & 0.50 & $\mathrm{Z}$ & $\mathrm{N}$ & 4 & 0.81 & Z \\
\hline A. pickeli & 1 & 1.11 & $\mathrm{Z}$ & $\mathrm{N}$ & - & - & & & - & - & & & - & - & \\
\hline $\begin{array}{c}\text { A. } \\
\text { hadropickeli }\end{array}$ & - & - & & & 1 & 0.32 & $\mathrm{Z}$ & $\mathrm{N}$ & - & - & & & - & - & \\
\hline A. barbiellini & - & - & & & - & - & & & - & - & & & 1 & 0.20 & Z \\
\hline C. capitata & 68 & 75.56 & $\mathrm{~W}$ & $\mathrm{D}$ & 51 & 16.19 & W & $\mathrm{D}$ & 14 & 3.50 & $\mathrm{Z}$ & $\mathrm{N}$ & 121 & 24.64 & $\mathrm{Y}$ \\
\hline Total & 90 & & & & 315 & & & & 400 & & & & 491 & & \\
\hline S & 6 & & & & 7 & & & & 7 & & & & 8 & & \\
\hline $\mathrm{H}^{\prime}$ & 0.8 & & & & 1.2 & & & & 1.0 & & & & 1.5 & & \\
\hline E & 0.4 & & & & 0.6 & & & & 0.5 & & & & 0.7 & & \\
\hline \multirow[t]{3}{*}{$\alpha$} & 1.1 & & & & 1.0 & & & & 1.0 & & & & 1.1 & & \\
\hline & \multicolumn{15}{|c|}{ BREJO PARAIBANO } \\
\hline & \multicolumn{4}{|c|}{ BORBOREMA } & \multicolumn{4}{|c|}{ MATINHAS } & \multicolumn{4}{|c|}{ PILÕES } & \multicolumn{3}{|c|}{ SERRARIA } \\
\hline SPECIES & $\mathrm{N}$ & $\mathrm{F}$ & $\mathrm{C}$ & $\mathrm{D}$ & $\mathrm{N}$ & $\mathrm{F}$ & $\mathrm{C}$ & $\mathrm{D}$ & $\mathrm{N}$ & $\mathrm{F}$ & $\mathrm{C}$ & $\mathrm{D}$ & $\mathrm{N}$ & $\mathrm{F}$ & $\mathrm{C}$ \\
\hline A. fraterculus & 184 & 75.41 & W & $\mathrm{D}$ & 12 & 33.33 & W & $\mathrm{D}$ & 73 & 80.22 & W & $\mathrm{D}$ & 72 & 13.58 & $\mathrm{Y}$ \\
\hline A. obliqua & 20 & 8.20 & $\mathrm{Z}$ & $\mathrm{N}$ & 11 & 30.56 & $\mathrm{Y}$ & $\mathrm{D}$ & 10 & 10.99 & $\mathrm{Y}$ & $\mathrm{N}$ & 337 & 63.58 & W \\
\hline A. sororcula & 27 & 11.07 & $\mathrm{Y}$ & $\mathrm{N}$ & 8 & 22.22 & $\mathrm{Y}$ & $\mathrm{D}$ & 5 & 5.49 & $\mathrm{Y}$ & $\mathrm{N}$ & 30 & 5.66 & $\mathrm{Z}$ \\
\hline A. antunesi & 10 & 4.10 & $\mathrm{Z}$ & $\mathrm{N}$ & - & - & & & - & - & & & 6 & 1.13 & $\mathrm{Z}$ \\
\hline A. distincta & 3 & 1.23 & $\mathrm{Z}$ & $\mathrm{N}$ & - & - & & & - & - & & & 2 & 0.38 & Z \\
\hline A. dissimilis & - & - & & & 1 & 2.78 & $\mathrm{Z}$ & $\mathrm{N}$ & 1 & 1.10 & $\mathrm{Z}$ & $\mathrm{N}$ & 8 & 1.51 & $\mathrm{Z}$ \\
\hline A. zenildae & - & - & & & - & - & & & - & - & & & 5 & 0.94 & Z \\
\hline A. pickeli & - & - & & & - & - & & & - & - & & & - & - & \\
\hline $\begin{array}{c}\text { A. } \\
\text { hadropickeli }\end{array}$ & - & - & & & - & - & & & - & - & & & - & - & \\
\hline A. barbiellini & - & - & & & - & - & & & - & - & & & - & - & \\
\hline C. capitata & - & - & & & 4 & 11.11 & $\mathrm{Y}$ & $\mathrm{N}$ & 2 & 2.20 & $\mathrm{Z}$ & $\mathrm{N}$ & 70 & 13.21 & $\mathrm{Y}$ \\
\hline Total & 244 & & & & 36 & & & & 91 & & & & 530 & & \\
\hline $\mathrm{S}$ & 5 & & & & 5 & & & & 5 & & & & 8 & & \\
\hline $\mathrm{H}^{\prime}$ & 0.8 & & & & 1.4 & & & & 0.7 & & & & 1.2 & & \\
\hline E & 0.5 & & & & 0.9 & & & & 0.4 & & & & 0.6 & & \\
\hline$\alpha$ & 0.7 & & & & 1.1 & & & & 0.9 & & & & 1.1 & & \\
\hline
\end{tabular}

$\mathrm{N}=$ Number of flies captured (females); $\mathrm{F}=$ Relative frequency $(\%) ; \mathrm{C}=$ Constancy $(\mathrm{w}=$ constant, $\mathrm{y}=$ accessory and $\mathrm{z}=$ accidental); $\mathrm{D}=$ Dominance $(\mathrm{d}=$ dominant and $\mathrm{n}=$ non-dominant $) ; \mathrm{S}=$ Richness; $\mathrm{H}^{\prime}=$ Shannon-Wiener diversity index; $\mathrm{E}=$ Evenness and $\alpha=$ Margalef diversity index.

Most species captured in the present study occurred at low population frequency. These species may have come from more distant hosts in relation to the place where the traps were installed and were eventually captured because of the attractiveness of the traps and the respective food attractants during their activity of exploring the environment. This fact has also been observed by Dutra et al. (2009) and 
Santos et al. (2011) in Bahia. Ferrara et al. (2005) highlighted that surveys made with traps probably enable the capture of fruit flies from more diverse vegetation, compared to the methodology of collecting tephritids through fruits.

According to the Shannon index, there was a difference in diversity between the areas, ranging from 0.7 to 1.5 , and the municipality of Bananeiras had the highest value, confirming the highest number of fruit fly species captured $(\mathrm{S}=8)$ among the other municipalities. The lowest value of this index was recorded for the municipality of Pilões, which can occur in areas where limiting factors and intraspecific competition act intensely on the population. Thus, in these areas the most common and dominant species increase their populations and the others have a low population level (Table 1).

The evenness index (E) ranged from 0.4 to 0.9 , and the municipalities of Alagoa Grande (0.4) and Pilões (0.4) had the lowest indices. The low evenness in these areas was due to the higher occurrence of two species with frequency greater than $75 \%$, namely $C$. capitata and A. fraterculus, respectively (Table 1). The same situation has been observed by Dutra et al. (2009) and Santos et al. (2011) in orchards located in the state of Bahia, where only two species of Anastrepha showed high frequency compared to the other species captured.

The Margalef diversity indices obtained were low, ranging from 0.7 to 1.1 (Table 1). According to Margalef (1972), this index rarely exceeds the value of 4.5 , usually ranging from 1.5 to 3.5 , where low values result from the higher dominance of some taxonomic groups to the detriment of the majority (BEGON; HARPER; TOWNSEND, 1996). The

Group 1

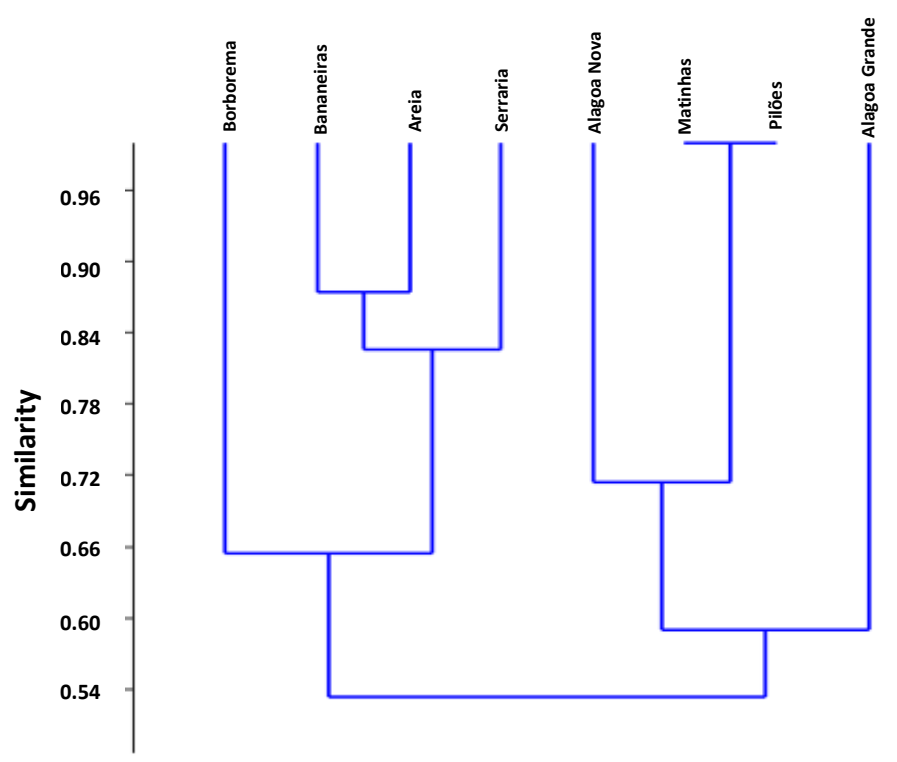

results of the present study demonstrate the occurrence of few dominant species of fruit flies, with populations of many individuals, in the eight municipalities studied (Table1). The results are similar to those obtained by Canal, Alvarenga and Zucchi (1998), who also obtained low diversity indices for fruit fly populations in northern Minas Gerais (1.19 to 2.26). The amount of fruit fly species captured by these authors did not vary greatly between municipalities, but the frequency of dominant species was always much higher, contrary to non-dominant species, represented only by some specimens.

In general, the low values of the indices found in all localities are due to the low diversity of fruit fly host plants, compared with diversified orchards or forests, which favors a low diversity of fruit fly species and the increase in the number of individuals of the most common species, as in the case of $A$. fraterculus, which prevailed in all orchards studied (AGUIAR-MENEZES et al., 2008; FERRAZ; GADELHA; AGUIAR-COELHO, 2009).

As for the composition of fruit fly species, the populations of Bananeiras, Borborema, Areia and Serraria (Group 1) were more similar to one another, forming a group different from that of the fruit fly populations of Alagoa Grande, Alagoa Nova, Matinhas and Pilões (Group 2) (Figure 1). In group 1 , there was a $66 \%$ quotient of similarity among the species, and all species captured in Borborema ( $A$. fraterculus, $A$. obliqua, $A$. sororcula, $A$. antunesi and A. distincta) were present in Bananeiras, Areia and Serraria. However, the greatest similarity observed in group 1 was between Areia and Bananeiras, with $88 \%$ of similar species.

\section{Group 2}

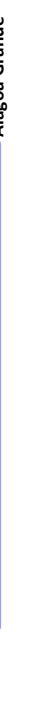

Figure 1. Cluster analysis between the eight municipalities of the Brejo Paraibano microregion (Group 1 - Borborema, Bananeiras, Areia and Serraria; Group 2 - Alagoa Nova, Matinhas, Pilões and Alagoa Grande), regarding the composition of fruit fly species, based on the quotient of similarity calculated by the Jaccard method (June/2015 - July/2016).

Rev. Caatinga, Mossoró, v. 34, n. 1, p. 242 - 248, jan. - mar., 2021 
The differences in species composition may be related, at least in part, to the variation in the composition of fruit fly host plants in the municipalities. In group 2, there was a quotient of similarity of $60 \%$ among the species, as almost all species contained in Alagoa Grande (A. fraterculus, A. obliqua, $A$. sororcula, $A$. distincta and $C$. capitata) were present in the other localities. The highest quotient of similarity observed in group 2 was between Matinhas and Pilões, with $100 \%$ equality between the species of these areas (Figure $1)$.

What can explain these clusters is the vegetation existing near the sampling areas of the municipalities studied, as suggested by Canal, Alvarenga and Zucchi (1998). These authors observed that in the urban area of the municipalities of Janaúba and Nova Porteirinha, MG, the fruit fly populations were $100 \%$ similar, while in the municipalities of Jaíba and Mocambinho, MG, located close to the native forest, the similarity between the populations was only $75 \%$.

The similarity obtained by the Jaccard method among all the municipalities studied was equal to $54 \%$, which indicates a high similarity between these orchards, in relation to species composition. AguiarMenezes et al. (2008) also obtained a quotient of similarity above $50 \%$ among diversified orchards in the state of Rio de Janeiro. According to AguiarMenezes et al. (2008) and Sá et al. (2012), the composition of host plants near the sampled orchards can influence the composition of species; in this case, the composition of plants contained in the orchards that were analyzed is virtually the same, composed mainly of plants that are part of the scenario of the Brejo Paraibano microregion.

\section{CONCLUSIONS}

Anastrepha fraterculus, $A$. obliqua and $A$. sororcula are present in the eight studied municipalities of the Brejo Paraibano microregion.

Anastrepha fraterculus is the most frequent, dominant and constant species.

Most species captured in the present study occur at low population frequency.

The municipalities studied have similarity of $54 \%$, which indicates a high similarity between the areas.

\section{ACKNOWLEDGMENTS}

The authors also thank Coordenação de Aperfeiçoamento de Pessoal de Nível Superior (CAPES), for granting scholarships.

\section{REFERENCES}

AGUIAR-MENEZES, E. L. et al. Análise faunística de moscas-das-frutas (Diptera: Tephritidae) nas regiões Norte e Noroeste do estado do Rio de Janeiro. Neotropical Entomology, 37: 8-14, 2008.

ALI, S. A. I. et al. Monitoring of Tephritidae of fruit trees and their level of infestation in South Kordofan State, Sudan. International Journal of Agriculture Innovations and Research, 2: 687-693, 2014.

ALVES, J. C. G. et al. Food attractants used in the fruit fly monitoring (Diptera: Tephritidae) in a commercial orchard of Psidium guajava. Journal of Experimental Agriculture International, 34: 1-10, 2019a.

ALVES, J. C. G. et al. Population fluctuation and faunistic analysis of fruit flies in a commercial guava orchard (Psidium guajava L.). Journal of Agricultural Science, 11: 1-9, $2019 \mathrm{~b}$.

ARAUJO, E. L. et al. Moscas-das-frutas (Diptera: Tephritidae) em um pomar de goiabeira, no semiárido brasileiro. Revista Brasileira de Fruticultura, 35: 471-476, 2013.

AZEVEDO, F. R. et al. Análise faunística e flutuação populacional de moscas-das-frutas (Diptera: Tephritidae) em pomares comerciais de goiaba na região do Cariri Cearense. Arquivos do Instituto Biológico, 77: 33-41, 2010.

BEGON, M.; HARPER, J. L.; TOWNSEND, C. R. Ecology: individuals, populations and communities. 3rd ed. Oxford, United Kingdom: Blackwell Scientific Publications, 1996. 1068 p.

CANAL, D. N. A.; ALVARENGA, C. D.; ZUCCHI, R. A. Análise faunística de espécies de moscas-dasfrutas (Dip., Tephritidae) em Minas Gerais. Scientia Agricola, 55: 15-24, 1998.

DEUS, E. G.; ADAIME, R. Dez anos de pesquisas sobre moscas-das-frutas (Diptera: Tephritidae) no estado do Amapá: avanços obtidos e desafios futuros. Biota Amazônia, 3: 157-168, 2013.

DUTRA, V. S. et al. Faunistic analysis of Anastrepha spp. (Diptera: Tephritidae) on a guava orchard under organic management in the municipality of Una, Bahia, Brasil. Neotropical Entomology, 38: 133-138, 2009.

FERRARA, F. A. A. et al. Análise faunística de moscas-das-frutas (Diptera: Tephritidae) da região Noroeste do estado do Rio de Janeiro. Neotropical Entomology, 34: 183-190, 2005. 
FERRAZ, A. C. P.; GADELHA, B. Q.; AGUIARCOELHO, V. M. Análise faunística de Calliphoridae (Diptera) da Reserva Biológica do Tinguá, Nova Iguaçu, Rio de Janeiro. Revista Brasileira de Entomologia, 53: 620-628, 2009.

HAMMER, Ø.; HARPER, D. A. T.; RYAN, P. D. Past: Paleontological statistics software package for education and data analysis. Palaeontologia Electronica, 4: 1-9, 2001.

HUSCH, P. E. et al. Caracterização da fauna de moscas-das-frutas (Diptera: Tephritidae) na região de Ponta Grossa, Paraná, Brasil. Ciência Rural, 42: 1833-1839, 2012.

MARGALEF, R. Homage to evelyn hutchinson, or why is there an upper limit to diversity. Transactions of the Connecticut Academy of Arts and Sciences, 44: 211-235, 1972.

MARSARO JÚNIOR, A. L. et al. Faunistic analysis of the species of Anastrepha Schiner (Diptera: Tephritidae) in three municipalities of the state of Roraima, Brazil. Brazilian Journal of Biology, 72: 813-819, 2012.

NORRBOM, A. L. et al. New species of Anastrepha (Diptera: Tephritidae) from Euphorbia tehuacana (Euphorbiaceae) in Mexico. Zootaxa, 3780: 567576, 2014.

ORDANO, M. et al. Temporal dynamics of diversity in a tropical fruit fly (Tephritidae) ensemble and their implications on pest management and biodiversity conservation. Biodiversity and Conservation, 22: 1557-1575, 2013.

PINTO-COELHO, R. M. Fundamentos em ecologia. 1.ed. Porto Alegre, Rio Grande do Sul: Artmed, 2000. 252 p.

SÁ, R. F. et al. Faunal analysis of the species Anastrepha in the fruit growing complex Gavido River, Bahia, Brazil. Bulletin of Insectology, 65: 37 $-42,2012$.

SANTOS, M. S. et al. Análise faunística e flutuação populacional de moscas-das-frutas (Diptera: Tephritidae) em Belmonte, Bahia. Revista Caatinga, 24: 86-93, 2011.

SILVA, J. G. et al. Population fluctuation of fruit flies (Diptera: Tephritidae) in domestic orchards in the Paraíba swamp region, Brazil. Journal of Experimental Agriculture International, 38: 1-9, 2019.

SILVEIRA NETO, S. Monitoramento e decisão no controle de pragas. In. WILSON, B. C. (Ed.). Manejo integrado de pragas. São Paulo: UNESPCETESB, 1990, v. 1, cap. 4, p. 71-86.

SOUTHWOOD, R. Sir. Ecological methods: with particular reference to the study of insect populations. 2nd ed. London, United Kingdom: Chapman and Hall, 1995. 524 p.

TAIRA, T. L. et al. Fruit flies (Diptera, Tephritidae) and their parasitoids on cultivated and wild hosts in the Cerrado-Pantanal ecotone in Mato Grosso do Sul, Brazil. Revista Brasileira de Entomologia, 57: 300-308, 2013.

ZUCCHI, R. A. Taxonomia. In: MALAVASI, A.; ZUCCHI, R. A. (Eds.). Moscas-das-frutas de importância econômica no Brasil: Conhecimento básico e aplicado. Ribeirão Preto: Holos Editora, 2000a, v. 2, cap. 1, p. 13-24.

ZUCCHI, R. A. Espécies de Anastrepha, sinonímias, plantas hospedeiras e parasitóides. In: MALAVASI, A.; ZUCCHI, R. A. (Eds.). Moscas-das-frutas de importância econômica no Brasil: Conhecimento básico e aplicado. Ribeirão Preto: Holos Editora, 2000b, v. 2, cap. 4, p. 41-48.

ZUCCHI, R. A.; MORAES, R. C. B. 2008. Fruit flies in Brazil - Anastrepha species their host plants and parasitoids. Disponível em: $<$ www.lea.esalq.usp.br/anastrepha $>$. Acesso em: 15 jan. 2020.

ZUCCHI, R. A.; MORAES, R. C. B. 2012. Fruit flies in Brazil - Hosts and parasitoids of the Mediterranean fruit fly. Disponível em: $<$ www.lea.esalq.usp.br/ceratitis/>. Acesso em: 17 jan. 2020. 